\title{
Eurasian badger (Meles meles) habitat and sett site selection in the northern Apennines
}

\section{Carlo M. Biancardi, Valentina Rigo, Sonia Azzolini, Claudio Gnoli}

Centro Studi Faunistica dei Vertebrati, Società Italiana di Scienze Naturali, C.so Venezia 55, I-20121 Milano, Italia. E-mail: csfv@scienzenaturali.org

Corresponding author: Carlo M. Biancardi, Centro Studi Faunistica dei Vertebrati, Società Italiana di Scienze Naturali, C.so Venezia 55, I-20121 Milano, Italia. E-mail: carlo.biancardi@gmail.com

\begin{abstract}
The principal aim of this research was to study coarsescale habitat selection and distribution of main setts of the Eurasian badger (Meles meles L., 1758). The study area extends for $161 \mathrm{Km}^{2}$ in the hilly territory of southern Lombardy (Italy). The positions of 23 main setts (SP) and 28 random points (RP) were mapped into a GIS. For each point, several environmental characteristics were measured in the field or taken from thematic digital maps. A statistical comparison of the distribution of these characteristics in a circular area (radius 300 $\mathrm{m}$ ) around each point was carried out. Eurasian badger setts were primarily dug in sheltered places, with high tree cover. The Manly selection index pointed to a strong selection for deciduous woods. Southern slope orientation and the presence of chestnut trees, a potentially important resource for badgers in this area, were also preferred. Similar to other studies, geological and lithological characters and the distance from water did not appear to influence den use. However, the substratum of the study area was mainly formed with sedimentary rocks, loam rocks and sandstones, with also easy-to-dig alluvial soils. Water is a resource easily available over the whole territory, with a well-branched network of rivers and streams. The road network and the presence of urban or industrial infrastructures seem to be a real factor of danger and disturbance, as one of the leading causes of mortality for badgers are road casualties. Our results suggest that badgers of this region are more selective for the sett site than for food resources.
\end{abstract}

Riassunto - Habitat del tasso (Meles meles) e ubicazione delle tane principali nell'Appennino settentrionale.

L'area di studio si estende per $161 \mathrm{Km}^{2}$ in un territorio collinare all'estremo sud della Lombardia (provincia di PV, Italia). L'area è compresa fra le coordinate UTM 4960000 e 4972000 Nord e fra 505000 e 520000 Est, che corrisponde alla val di Staffora, fra 300 e $800 \mathrm{~m}$ s.l.m. Scopo principale di questa ricerca era lo studio delle preferenze ambientali del tasso (Meles meles L., 1758) in relazione alla ubicazione delle tane principali. Le posizioni di 23 tane principali e di 28 punti casuali sono state inserite in un GIS e, per ognuna, sono state misurate sul posto diverse caratteristiche ambientali. Altri parametri sono stati ricavati da carte digitali tematiche. E' stata analizzata con tecniche statistiche la distribuzione delle caratteristiche ambientali in un'area circolare (raggio $300 \mathrm{~m}$ ) intorno alle tane e ai punti casuali. Le tane di tasso sono prevalentemente ricavate in luoghi riparati, con buona copertura arborea. L'indice di selezione di Manly indica una forte preferenza per boschi decidui. Risultano preferiti i versanti esposti a sud e la presenza di castagni, importante risorsa trofica per la specie in quest'area. Le caratteristiche litologiche e geologiche, così come la distanza dall'acqua, non sembrano essere importanti fattori di scelta, in accordo anche con i risultati di altri studi analoghi. Il substrato dell'area di studio è formato principalmente da rocce sedimentarie, marne e arenarie, accompagnate da terreni alluvionali, facili da scavare. L'acqua è una risorsa ampiamente disponibile sul territorio, con una rete di corsi d'acqua molto ramificata. La rete viaria e la presenza di infrastrutture urbane e industriali pare invece essere un fattore di disturbo importante. I nostri risultati indicano che questa specie sembra essere più selettiva nei confronti delle caratteristiche ambientali che non per la presenza di risorse alimentari.

Key-words: badger, Meles meles, habitat selection, sett distribution, Northern Italy.

\section{INTRODUCTION}

The Eurasian badger (Meles meles L., 1758) is widely distributed across the Western Palaearctic region (Roper, 2010). Although belonging to the order of Carnivores, badgers are opportunistic omnivores, and their diet is extremely varied across their geographical range and, within populations, across seasons (Roper, 2010). Their apparent behavioural plasticity allows badgers to occupy different habitats, ranging from boreal and deciduous forests and pastures, to Mediterranean habitats and steppes (Roper, 2010). In Italy, the species is distributed across the whole peninsula, except on islands (Boitani et al., 2003).

Habitat fragmentation is known to be one of the factors affecting badger populations (Pertoldi et al., 2001; Virgós, 2002); for this reason, it has been selected as a focal species for ecological network planning (Bani et al., 2002; Amici and Battisti, 2009). However, the impact of habitat fragmentation can be perceived at different levels: shortage of food and water, lacking of suitable places for digging a sett, risk of casualties due to road network. Each of these variables can be considered as limiting factor for badgers (Doncaster and Woodroffe, 1993; Macdonald et al., 2004; Rosalino et al., 2005).

Centro Studi Faunistica dei Vertebrati, a working group of the Società Italiana di Scienze Naturali (SISN), carried out a long series of studies of badger populations in Lombardy (North of Italy) (Biancardi and Rinetti, 1995, 1998, 1999 and 2004; Boesi and Biancardi, 2002; Marassi and Biancardi, 2002). The aim of the present work is to evaluate the most important factors influencing habitat selection by badgers in this study region, by measuring the spatial relationship of sett locations to surrounding resources. 


\section{MATERIALS AND METHODS \\ Study area}

The study area $\left(161 \mathrm{~km}^{2}\right)$ is included within the coordinates $44^{\circ} .790-44^{\circ} .930 \mathrm{~N}$ and $9^{\circ} .060-9^{\circ} .250 \mathrm{E}$ (Decimal degrees). It lies in the north of Italy, in the most southern part of Lombardy, corresponding to the middle valley of stream Staffora, between 300 and $800 \mathrm{~m}$ a.s.l. (Fig. 1). The area is included in the Continental biogeographic region. Geologically the northern Apennine area is comprised by layers of marls, clays and sandstones, resulting from the superimposition of different layers, resulting from the collision between the Adriatic and the European tectonic plates.

\section{Setts}

Within that area, 48 badger setts were detected and plotted onto a base map. Sett sites have been found thanks to information collected from local forest rangers, game wardens and hunters. For each sett we recorded the geographic position, by means of a GPS device (Garmin ltd.), as well as a set of data: sett size and linear extension, whether it was actively used or not, number of entrances, their conditions and dimensions, presence of signs or tracks, spoil heap, and latrines number and size.

In situations of low population density, as in Mediterranean and mountain areas, the "classic" classification of badger setts (Thornton, 1988) is no longer applicable (Revilla et al., 2001). For the aims of the present study, we decided to consider as "annexes" minor shelters located near larger setts and clearly connected to them. After a first evaluation and classification, 23 main setts were chosen for the habitat preferences analysis, on the basis of their size and signs of frequent occupation (Fig. 1).

\section{Random points and data collection}

A series of random points coordinates, within the study area, was set using a random number generator. The number of points (28) was chosen to be in the same order of size than the sett points. The coordinates of all the sett points (SP) and random points (RP) were plotted in a GIS (Quantum GIS, OSGeo project, Fig. 1) and, through the available layers, a first set of variables were filled with data calculated within $300 \mathrm{~m}$ and $600 \mathrm{~m}$ of each SP and RP. The layers used in this analysis were: CTR (Carta Tecnica Regionale), Soil use (DUSAF1), Lithology, Geology, DEM, Slopes and aspects (former ERSAL, ARF, Geoportale Regione Lombardia). Vectorial layers for Streams, Roads, Setts and Random points were digitised by the authors.

A second set of variables were measured or estimated during the first visit of each SP and RP, and recorded. See Tabs. 1 and 3 for the detailed description of each variable included in the analysis.

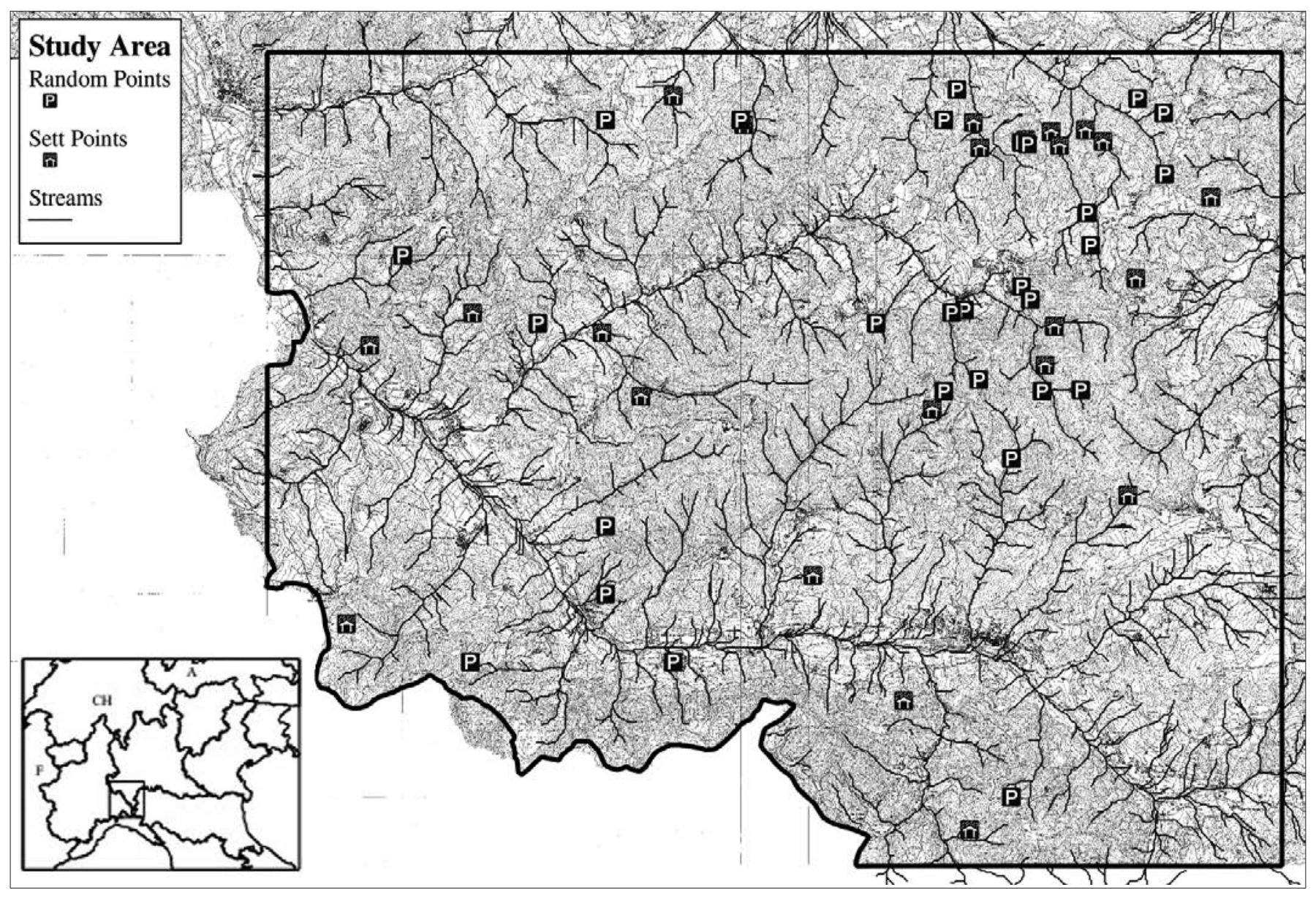

Fig. 1 - Geographic position of the study area, with Sett Points, Random Points and water (rivers and streams) layer. 
Tab. 1 - List of variables included in the analyses. Class (for categorical or ordinal variables): in bold the categories more correlated to Sett Points (positively +, negatively -); Manly: the selection index; $p=$ statistical significance; "*" = variable included into the logistic regression model.

\begin{tabular}{|c|c|c|c|c|c|}
\hline Variable & Description & Class & Manly & Univariate stat & $\begin{array}{c}\text { Multivariate } \\
\text { logistic regression }\end{array}$ \\
\hline \multirow[t]{4}{*}{ HAB } & Habitat & Deciduous (+) & 0.71 & $\mathrm{P}<0.001$ & $*$ \\
\hline & & Conifers & & & \\
\hline & & Shrubs & & & \\
\hline & & Rural & & & \\
\hline \multirow[t]{2}{*}{ TREE } & Distance from the nearest tree & $<2 \mathrm{~m} \mathrm{(+)}$ & 0.89 & $\mathrm{P}=0.005$ & $*$ \\
\hline & & $>2 \mathrm{~m}$ & & & \\
\hline \multirow[t]{2}{*}{ SHRUB } & Distance from the nearest shrub & $<2 \mathrm{~m} \mathrm{(+)}$ & 0.95 & $\mathrm{P}<0.001$ & $*$ \\
\hline & & $>2 \mathrm{~m}$ & & & \\
\hline \multirow[t]{4}{*}{ TCOV } & Trees coverage & $0-25 \%$ & & $\mathrm{P}=0.018$ & \\
\hline & & $25-50 \%$ & & & \\
\hline & & $50-75 \%(+)$ & 0.61 & & \\
\hline & & $75-100 \%$ & & & \\
\hline \multirow[t]{4}{*}{ SCOV } & Shrubs coverage & $0-25 \%$ & & $\mathrm{P}=0.004$ & \\
\hline & & $25-50 \%$ & & & \\
\hline & & $50-75 \%(+)$ & 0.51 & & \\
\hline & & $75-100 \%$ & & & \\
\hline \multirow[t]{4}{*}{ GCOV } & Grass coverage & $0-25 \%$ & & $P=0.972$ & \\
\hline & & $25-50 \%$ & & & \\
\hline & & $50-75 \%(+)$ & 0.36 & & \\
\hline & & $75-100 \%$ & & & \\
\hline \multirow[t]{4}{*}{ SOIL } & Free soil & $0-25 \%$ & & $P=0.892$ & \\
\hline & & $25-50 \%$ & & & \\
\hline & & $50-75 \%(+)$ & 0.4 & & \\
\hline & & $75-100 \%$ & & & \\
\hline ROCKS & Rocky terrain & Presence & & & \\
\hline CHEST & Chestnut trees & Presence $(+)$ & 0.79 & $\mathrm{P}=0.013$ & \\
\hline ORCH & Orchards & Presence (-) & 0.92 & $\mathrm{P}=0.003$ & \\
\hline \multirow[t]{2}{*}{ ASPECT } & Sett slope orientation & W-N-E (-) & 0.07 & $\mathrm{P}<0.001$ & $*$ \\
\hline & & SE-S-SW (+) & 0.93 & & \\
\hline SLOPE & Slope gradient & $\begin{array}{c}8 \text { classes }(0- \\
100 \%)\end{array}$ & & n.s. & \\
\hline GEO & Geology & 21 classes & & n.s. & \\
\hline LITHO & Lithology & 11 classes & & n.s. & \\
\hline \multirow[t]{2}{*}{ USE } & Soil use & $\begin{array}{c}\text { Urban, } \\
\text { industrial and } \\
\text { quarries (-) }\end{array}$ & & $\mathrm{P}=0.033$ & \\
\hline & & Other 11 classes & & & \\
\hline PROAN & Provincial road network & within $300 \mathrm{~m}$ & & $P=0.245$ & \\
\hline MROAN & Municipal road network & within $300 \mathrm{~m}(-)$ & & $\mathrm{P}=0.002$ & $*$ \\
\hline GROAN & Gravel road network & within $300 \mathrm{~m}$ & & $P=0.141$ & $*$ \\
\hline
\end{tabular}


Environments were classified as Deciduous woodlands, Conifer, Shrubs or Rural. The distances from the nearest tree or shrub were categorised as within or farther than $2 \mathrm{~m}$. Percentages of cover by trees, shrubs, grass, free soil or rocks were categorised in 4 classes $(0-25 \%$; $25-50 \% ; 50-75 \% ; 75-100 \%)$. In order to evaluate the position of the estimated centre of the sett (peak, hollow, flat or on a slope), the slope gradient in the four points of the compass has been categorised as positive (uphill), negative (downhill) or on level.

The geological GIS layer comprised 21 classes, the most common being different type of sandstones $(30 \%)$ and marl (25\%). Lithology was split in 11 classes, primarily represented by low plasticity clayish fluvial deposits (30\%) and sandy substratum (17\%). The most common class of land use $(41.3 \%)$ was represented by arable patches, followed by copse woodlands (34.4\%). Other 10 classes of land use were of minor account.

Roads were divided into provincial expressways, municipal roads and dirty roads. The minimum distance from each SP and RP, and the magnitude of the road network within $300 \mathrm{~m}$ from every point, were calculated for all road categories. The minimum distance of water resources and of urban areas from SP and RP were calculated as well.

\section{Habitat selection}

Habitat selection can be considered to be part of the more general question of the selection of resources by animal individuals or populations (Manly et al., 2002). Of the four basic study designs described by Thomas and Taylor $(1990 ; 2006)$ and generalized by Manly et al. (2002), we applied the following:

use, non-use and availability of resources were sampled and collected at population level, while individual animals were not identified.

As it compares the habitat composition values ("use") at badger setts with those at random chosen points within the study area ("availability"), our study design can be included in the first category (Manly et al., 2002; Thomas and Taylor, 2006). We calculated the resource selection index " $w$ " (Savage, 1931) and its standardised form " $B$ " (Manly et al., 2002). The resource selection index value for any variable " $i$ " $\left(w_{i}\right)$ of the total number $(n)$ of considered variables, is defined as the ratio between the proportion of the variable " $i$ " at sett points $\left(S p_{i}\right)$ and the proportion of the same variable at random points $\left(R p_{i}\right)$ :

$$
w_{i}=\frac{S p_{i}}{R p_{i}}
$$

The standardised form is defined as:

$$
B=\frac{w_{i}}{\sum_{i=1}^{n} w_{i}}
$$

Values of $B$ range between 0 and 1.
Univariate tests (U Mann-Whitney and Chi-square) were performed on all the recorded variables. Among the multivariate techniques of analysis, logistic regression is especially recommended when the dependent variable is binary. Furthermore, it is the most robust technique in case of mixed data-sets, with binary, categorical and continuous variables (McGarigal et al., 2000). The dependent variable was coded as $0=\mathrm{RP} ; 1=\mathrm{SP}$. Different predictive models have been built, based on results of the univariate and resource selection analyses. This "a priori modelling" approach can avoid the inferential problems related to multicollinearity among variables (Graham, 2003).

Models were compared on the basis of the change in the Akaike Information Criterion corrected for small sample size (AICc) (Burnham and Anderson, 2002) and by receiver operating characteristic-area under curve (ROC-AUC) statistics. If two or more models had similar AICc values $(\triangle \mathrm{AICc}<4)$, we calculated the Akaike weights of each model and performed a model averaging as suggested by Royall (1997). Statistical analyses were carried out with the package SPSS (v.18, SPSS Inc.).

\section{RESULTS \\ Setts}

Within the study area, 48 setts were found. The average number of entrances of the main setts was nearly 15 $(14.9 \pm 7.4 \mathrm{SD}$; range $5-35$; median $=14)$, while the other setts had on average 3-4 entrances (3.4 \pm 2.8 SD; range $1-12$; median 3 ). A spoil heap was present outside $3.9 \pm 3.8 \mathrm{SD}$ holes per sett (range $0-15$; median 3 ). The maximum distance between two entrances of the same sett was taken as an index of sett dimensions; results are shown in Tab. 2.

Tab. 2 - Frequency of occurrence of categorical sett extension. Distance: largest linear distance between two entrances of the same sett.

\begin{tabular}{|c|c|c|}
\hline Distance & Frequency & \% \\
\hline$<1 \mathrm{~m}$ & 10 & $22 \%$ \\
\hline $1-5 \mathrm{~m}$ & 6 & $13 \%$ \\
\hline $5-10 \mathrm{~m}$ & 1 & $2 \%$ \\
\hline $10-20 \mathrm{~m}$ & 8 & $18 \%$ \\
\hline $20-50 \mathrm{~m}$ & 17 & $38 \%$ \\
\hline$>50 \mathrm{~m}$ & 3 & $7 \%$ \\
\hline
\end{tabular}

The entrances were not circular, the average width measured $52.8 \mathrm{~cm} \pm 21.5 \mathrm{SD}$, while the average height was $33.7 \mathrm{~cm} \pm 13.1 \mathrm{SD}$.

The minimum distance of a sett from water, roads and urban areas are shown in Tab. 3 . 
Tab. 3 - Minimum distance from water, roads and urban areas. U = Mann-Whitney U-test value; Sig. = statistical significance (P).

\begin{tabular}{|l|c|c|c|c|c|}
\hline Distance from & SP/ RP & $\begin{array}{c}\text { Range } \\
(\mathbf{m})\end{array}$ & $\begin{array}{c}\text { Median } \\
(\mathbf{m})\end{array}$ & U & Sig. \\
\hline Water & Setts & $12-360$ & 134 & 315.5 & $P=0.902$ \\
\hline & R. Points & $20-380$ & 117 & & \\
\hline Village, town & Setts & $208-1794$ & 668 & 245.5 & $P=0.148$ \\
\hline & R. Points & $0-1721$ & 456 & & \\
\hline Provincial road & Setts & $87-1436$ & 586 & 246.5 & $P=0.153$ \\
\hline & R. Points & $1-1810$ & 381.5 & & \\
\hline Municipal road & Setts & $57-1587$ & 654 & 180 & $P=0.007$ \\
\hline & R. Points & $11-2157$ & 236 & & \\
\hline Dirty road & Setts & $15-586$ & 235 & 274.5 & $P=0.809$ \\
\hline & R. Points & $2-2027$ & 162.5 & & \\
\hline
\end{tabular}

\section{Habitat preferences}

Considering all the data collected at setts and random points, or within an area of $300 \mathrm{~m}$ of radius from them, in a multivariate logistic regression analysis, different models have been built. The first six models, ordered per decreasing AICc, are shown in Tab. 4. Models 2 and 3 showed $\triangle \mathrm{AICc}$ $<4$ with respect to model 1 , therefore the Akaike weight of each model has been taken into consideration. The six factors (signed as * in Tab. 1) proved influential according to the sum of the weights of the models in which they are included (Tab. 5). The three models are good at separating setts to random points, with an area under the curve $=0.877$.

Four factors (SHRUB, ASPECT, MROAN, GROAN) were present in all three models, and therefore had a weight $=1$. The presence of shrubs or small trees within 2 meters from a sett point was far more probable than within the same distance from a random point. This variable showed a high value of Manly's standardised selection index $(\mathrm{B}=0.95)$. With regards to orientation, there was a greater likelihood of setts occurring on south facing slopes than predicted from random chance $(B=0.93)$. The presence of a network of municipal or gravel roads within $300 \mathrm{~m}$ from the investigated point was negatively correlated with badger setts. However, only the network of municipal roads and the minimum distance from them was significantly different in the univariate non-paramet- ric tests (MROAN: Mann-Whitney $\mathrm{U}=467, \mathrm{P}=0.002$; MROAD: Mann-Whitney $\mathrm{U}=180, \mathrm{P}=0.007$ ).

The coefficient of the independent variable HAB was negative, pointing to lower probability to find setts in open rural or urban areas. Present in one model, its weight was 0.31 . Manly's index pointed to a strong selection for broadleaf woodlands $(\mathrm{B}=0.71)$. The distance from the nearest tree had a weight of 0.24 . The probability to find a tree within 2 meters was higher for setts than for random points: Manly's index for distance $<2 \mathrm{~m}=0.89$.

Other variables showed a statistically significant relationship between SP characteristics and RP; all of the following occurred more frequent within $300 \mathrm{~m}$ of random points than of sett points (Tab. 1): the coverage of trees and shrubs (TCOV: Manly's index for cov. $50-75 \%=$ $0.61, X^{2}=8.02, \mathrm{P}=0.018$; SCOV: Manly's index for cov. $\left.50-75 \%=0.51, X_{2}^{2}=10.86, \mathrm{P}=0.004\right)$, the presence of chestnut trees (CHEST: Manly's index $=0.79, X^{2}{ }_{1}=6.22$, $\mathrm{P}=0.013)$, the absence of orchards (ORCH: Manly's in$\operatorname{dex}=0.92, X^{2}{ }_{1}=9.04, \mathrm{P}=0.003$ ), the category "urban, industrial and quarries areas" of soil use, more frequent within $300 \mathrm{~m}$ of random points than of sett points (MannWhitney $\mathrm{U}=182, \mathrm{P}=0.033$ ).

Conversely, geological categories, lithological ones, distance from water or from villages did not show any statistical significance.

Tab. 4 - Logistic regression models. AICc = Akaike Information Criterion corrected for small sample size; $\triangle \mathrm{AICc}=$ Delta AICc; ROC$\mathrm{AUC}=$ Receiver Operating Characteristic-Area Under Curve (range $0-1)$; Weight $=$ Akaike weight of the model $($ range $0-1)$.

\begin{tabular}{|c|l|c|c|c|c|}
\hline Model & Factors & AICc & AAICc & ROC-AUC & Weight \\
\hline 1 & SHRUB + ASPECT + MROAN + GROAN & 38.42 & - & 0.887 & 0.45 \\
\hline 2 & HAB + SHRUB + ASPECT + MROAN + GROAN & 40.17 & 1.75 & 0.887 & 0.31 \\
\hline 3 & TREE + SHRUB + ASPECT + MROAN + GROAN & 40.71 & 2.29 & 0.887 & 0.24 \\
\hline 4 & TREE + SHRUB + TCOV + SCOV + ASPECT + MROAN + GROAN & 45.66 & 7.24 & 0.815 & - \\
\hline 5 & SHRUB + SCOV + ASPECT & 53.02 & 14.60 & 0.812 & - \\
\hline 6 & SHRUB + MROAN + GROAN & 59.35 & 20.93 & 0.732 & - \\
\hline
\end{tabular}


Tab. 5. Weight of the factors after averaging modelling. Model 1-3= Akaike weight of the factor in each model; Weight $=$ Total weight of the factor (range $0-1$ ).

\begin{tabular}{|l|c|c|c|c|}
\hline Factors & Model 1 & Model 2 & Model 3 & Weight \\
\hline SHRUB & 0.45 & 0.31 & 0.24 & 1.00 \\
\hline ASPECT & 0.45 & 0.31 & 0.24 & 1.00 \\
\hline MROAN & 0.45 & 0.31 & 0.24 & 1.00 \\
\hline GROAN & 0.45 & 0.31 & 0.24 & 1.00 \\
\hline HAB & 0.00 & 0.31 & 0.00 & 0.31 \\
\hline TREE & 0.00 & 0.00 & 0.24 & 0.24 \\
\hline
\end{tabular}

\section{DISCUSSION}

The most important feature that appeared to determine sett site selection in this study site was the tree and shrub coverage. Indeed, all the related variables, such as the nearest tree and nearest shrub distances, the actual coverage percentage, and the deciduous woodlands, proved to be positively selected. Deciduous woodlands have also been shown to be selected for in similar studies, even in different environments, (Matyáštík and Bíčik, 1999; Virgos and Casanovas, 1999; Bíčik et al., 2000; Good et al., 2001; Revilla et al., 2001; Rosalino et al., 2008; Balestrieri et al., 2009; Myslajek et al., 2012). Coniferous forests did not appear to be positively selected, but their occurrence in the study area is poor. This outcome corroborates with the results of other research in similar regions (Good et al., 2001; Revilla et al., 2001). Even in northern Europe, where coniferous forests are widespread, badgers mostly use patches of deciduous forests (Brøseth et al., 1997), and reach higher densities in mixed woodlands (Kahuala and Holmala, 2011).

Open areas such as orchards, cultivated, and urban areas were generally avoided (Balestrieri et al., 2009; Kahuala and Auttila, 2010; Myslajek et al., 2012), although in Mediterranean semi-arid environments fruit orchard and rocky covered areas are used (Lara-Romero et al., 2012).

Slope orientation to south and southeast were respectively selected by Manly index and logistic regression. The same slope preferences were detected in central Europe (Matyáštík and Bíčik, 1999; Bíčik et al., 2000; Myslajek et al., 2012). Conversely, in Spain northern and eastern slopes were positively selected (Revilla et al., 2001), and finally in the UK (Oxfordshire) northwestern facing slopes were preferred (Macdonald et al., 2004). Those differences may be explained by the diverse climatic conditions of the mountain slopes in the different geographic areas. Our study area belongs to the Continental biogeographic region, like large part of the central Europe, where northern slopes are generally cold, while southern have milder conditions. Conversely, Spain belongs to the Mediterranean biogeographic region, where southern slopes are generally dry and hot during summertime, while northern present more temperate conditions. In the region investigated by Macdonald et al. (2004) the northwestern slopes could assure shelter against the cold eastern winds. These results suggest that badgers tend to prefer mild environments, and to avoid too cold or too arid conditions.

While soil conditions can affect the activity patterns of badgers (Do Linh San et al., 2007b), no geological or soil factor was selected in our analyses, the existence of ridges and particular soil characteristics have been indicated as limiting factors in Spain and Portugal (Revilla et al., 2001; Rosalino et al., 2005). Water is rather abundant in our study area, which may explain why the distance from the nearest stream or water body was not a factor of selection. The same result has been found in many similar studies (e.g. Virgos and Casanovas, 1999; Good et al., 2001).

In almost all studies, factors related to human disturbance, such as roads, houses, urban and industrial settlements, were negatively selected. Road traffic accidents are the leading causes of mortality for badgers in many areas where road infrastructures are well developed (Di Giulio et al., 2009), even if the casualties follow a seasonal pattern (Macdonald et al., 2010).

Water, food and shelter place availability are considered the most important driver factors of habitat selection for badgers. In different parts of their wide geographical range, however, one or the other factor can take charge, depending on the environmental constraints (Virgos and Casanovas, 1999; Revilla et al., 2000; Zabala et al., 2002; Rosalino et al., 2005; Do Linh San et al., 2007a; Loureiro et al., 2007). In our study area badgers selected mildtemperate valleys and slopes, with an adequate tree and shrub coverage and wide possibilities to find shelter and digging holes. Even when they exploited human-related feeding resources, they were inclined to avoid anthropic disturbance around their main setts.

\section{Acknowledgements}

We would like to thanks: the former Azienda Regionale Foreste, Ente Regionale Sviluppo Agricolo della Lombardia (currently ERSAF), GeoPortale Regione Lombardia and the Comunità Montana Oltrepò Pavese, which delivered precious information and digital layers and maps. Paola Mariani for assistance and support in GIS. We are grateful to all the people who delivered precious information and helped during the fieldwork, in particular: Anna Rita Di Cerbo, Claudio Dirotti, Maurizio Ferrari, Tiziana Gambacorta, Piero Lucchelli, Luigi Marenzi, Graziella Moglia, Paolo Zambianchi, Antonio, Ferruccio, Francesco e Walter. We also thanks three anonymous reviewers for their precious suggestions and their corrections of the English text. Finally, thanks to the badgers of Oltrepò hills.

\section{REFERENCES}

Amici V. \& Battisti C., 2009 - Selecting Focal Species in Ecological Network Planning following an ExpertBased Approach: A Case Study and a Conceptual Framework. Landscape Research, 34 (5): 545-561.

Balestrieri A., Remonti L. \& Prigioni C., 2009 - Habitat selection in a low-density badger Meles meles population: a comparison of radio-tracking and latrine surveys. Wildlife Biology, 15: 442-448. 
Bani L., Baietto M., Bottoni L. \& Massa R., 2002 - The use of focal species in designing a habitat network for a lowland area of Lombardy, Italy. Conservation Biology, 16 (3): 826-831.

Biancardi C. M. \& Rinetti L., 1995 - Analisi della alimentazione del Tasso, Meles meles (L.), nell'Alto Luinese (Provincia di Varese, Italia) (Mammalia, Mustelidae). Atti della Società italiana di Scienze naturali e del Museo civico di Storia naturale in Milano, 134 (2): 265-280.

Biancardi C. M. \& Rinetti L., 1998 - Distribuzione dei sistemi di tana di Tasso (Meles meles L., 1758) nell'Alto Luinese (Provincia di Varese, Lombardia, Italia) (Mammalia, Mustelidae). Atti della Società italiana di Scienze naturali e del Museo civico di Storia naturale in Milano, 139 (1): 57-64.

Biancardi C. M. \& Rinetti L., 1999 - Badgers (Meles meles L., 1758) in a mountain area north of Varese (Lombardy - Italy). Small Carnivore Conservation, 21: 3-5.

Biancardi C. M. \& Rinetti L., 2004 - Trophic niche overlap of three carnivores in a mountain area north of Varese (Lombardy, Italy). Small Carnivore Conservation, 30: 11-13.

Bíčik V., Foldynová S. \& Matyáštík T., 2000 - Distribution and habitat selection of badger (Meles meles) in southern Moravia. Acta Universitatis Palackianae Olomucensis, Facultas Rerum Naturalium, Biologie, 38: $29-40$.

Boesi R. \& Biancardi C. M., 2002 - Diet of the Eurasian badger Meles meles (Linnaeus, 1758) in the Natural Reserve of Lago di Piano, northern Italy. Mammalian Biology, 67 (2): 120-125.

Boitani L., Lovari S. \& Vigna Taglianti A. (eds.), 2003 - Fauna d'Italia. Mammalia III. Carnivora, Artiodactyla. Calderini, Bologna.

Broseth H., Knutsen B. \& Bevanger K., 1997 - Spatial organization and habitat utilization of badgers Meles meles: effects of food patch dispersion in the boreal forest of central Norway. Zeitschrift fur Saugetierkunde, 62: 12-22.

Burnham K. P. \& Anderson D. R., 2002 - Model Selection and Inference: A Practical Information Theoretic Approach (second edition). Springer-Verlag, New York.

Di Giulio M., Holderegger R. \& Tobias S., 2009 - Effects of habitat and landscape fragmentation on humans and biodiversity in densely populated landscapes. Journal of Environmental Management, 90 (10): 2959-2968.

Do Linh San E., Ferrari N. \& Weber J. M., 2007a - Sociospatial organization of Eurasian badgers (Meles meles) in a low-density population of central Europe. Canadian Journal of Zoology, 85 (9): 973-984.

Do Linh San E., Ferrari N. \& Weber J. M., 2007b - Spatio-temporal ecology and density of badgers Meles meles in the Swiss Jura Mountains. European Journal of Wildlife Research, 53 (4): 265-275

Doncaster C. P. \& Woodroffe R., 1993 - Den site can determine shape and size of badger territories: implications for group-living. Oikos, 66: 88-93.

Good T. C., Hindenlang K. \& Imfeld S., 2001 - A habitat analysis of badger (Meles meles L.) setts in a seminatural forest. Mammalian Biology, 66: 204-214.
Graham M. H., 2003 - Confronting multicollinearity in ecological multiple regression. Ecology, 84 (11): 2809-2815.

Kauhala K. \& Auttila M., 2010 - Habitat preferences of the native badger and the invasive raccoon dog in southern Finland. Acta Theriologica, 55 (3): 231240.

Kauhala K. \& Holmala K., 2011 - Landscape features, home-range size and density of northern badgers Meles meles. Annales Zoologici Fennici, 48: 221232.

Lara-Romero C., Virgós E. \& Revilla E., 2012 - Sett density as an estimator of population density in the European badger Meles meles. Mammal Review, 42: 78-84.

Loureiro F., Rosalino L. M., Macdonald D. W. \& SantosReis M., 2007 - Path tortuosity of Eurasian badgers (Meles meles) in a heterogeneous Mediterranean landscape. Ecological Research, 22 (5): 837-844.

Macdonald D. W., Newman C., Buesching C. D. \& Nouvellet P., 2010 - Are badgers 'Under The Weather'? Direct and indirect impacts of climate variation on European badger (Meles meles) population dynamics. Global Change Biology, 16 (11): 2913-2922.

Macdonald D. W., Newman C., Dean I., Buesching C. D. \& Johnson P. J., 2004 - The distribution of Eurasian badger, Meles meles, sett in a high- density area: field observations contradict the sett dispersion hypothesis. Oikos, 106: 295-307.

Manly B. F. J., McDonald L. L., Thomas D. L., McDonald T. L. \& Erickson W. P., 2002 - Resource selection by animals. Kluwer Academic Publishers, Boston.

Marassi M. \& Biancardi C. M., 2002 - Diet of the Eurasian badger (Meles meles) in an area of the Italian Prealps. Hystrix, 13: 19-28.

Matyáštík T. \& Bíčik V., 1999 - Distribution and habitat selection of badger (Meles meles) in northern Moravia. Acta Universitatis Palackianae Olomucensis, Facultas Rerum Naturalium, Biologie, 37: 77-88.

McGarigal K., Cushman S. \& Stafford S., 2000 - Multivariate statistics for wildlife and ecology research. Springer-Verlag, New York.

Myslajek R., Nowak S. \& Jedrzejewska B., 2012 - Distribution, characteristics and use of shelters by the Eurasian badger Meles meles along an altitudinal gradient in the Western Carpathians, S Poland. Folia Zoologica, 61: 152-160.

Pertoldi C., Loeschcke V., Madsen A. B., Randi E. \& Mucci N., 2001 - Effects of habitat fragmentation on the Eurasian Badger (Meles meles) subpopulations in Denmark. Hystrix, 12 (1): 1-6.

Revilla E., Palomares F., \& Delibes M., 2000 - Defining key habitats for low density populations of Eurasian badgers in Mediterranean environments. Biological Conservation, 95 (3): 269-277.

Revilla E., Palomares F. \& Fernández N., 2001 - Characteristics, location and selection of diurnal resting dens by Eurasian badgers (Meles meles) in a low density area. Journal of Zoology, London, 255: 291-299.

Roper T. J., 2010 - Badger. Collins, London. 
Rosalino L., Macdonald D. \& Santos-Reis M., 2005 Resource dispersion and badger population density in Mediterranean woodlands: is food, water or geology the limiting factor? Oikos, 110: 441-452.

Rosalino L. M., Santos M. J., Beier P. \& Santos-Reis M., 2008 - Eurasian badger habitat selection in Mediterranean environments: Does scale really matter? Mammalian Biology, 73 (3): 189-198.

Royall R. M., 1997 - Statistical evidence: a likelihood paradigm. Chapman \& Hall, New York.

Savage R. E., 1931 - The relation between the feeding of the herring off the East coast of England and the plankton of the surrounding waters. Ministry of Agriculture and Fisheries, Fishery Investigations, London, Series 2, 12 (3): 1-88.

Thomas D. L. \& Taylor E. J., 1990 - Study designs and tests for comparing resource use and availability. Journal of Wildlife Management, 54: 322-330.
Thomas D. L. \& Taylor E. J., 2006 - Study designs and tests for comparing resource use and availability II. Journal of Wildlife Management, 70: 324-336.

Thornton P., 1988 - Density and Distribution of Badgers in Southwest England - A Predictive Model. Mammal Review, 18: 11-23.

Virgós E., 2002 - Are habitat generalists affected by forest fragmentation? A test with Eurasian badgers ( $\mathrm{Me}$ les meles) in coarse-grained fragmented landscape of central Spain. Journal of Zoology, London, 258: 313318.

Virgós E. \& Casanovas J. G., 1999 - Badger Meles meles sett site selection in low density Mediterranean areas of central Spain. Acta Theriologica, 44: 173-182.

Zabala J., Garin I., Zuberogoitia I. \& Aihartza J., 2002 Habitat selection and diet of badgers (Meles meles) in Biscay (northern Iberian Peninsula). Italian Journal of Zoology, 69 (3): 233-238. 